KUML 1997-98 


\section{KUML 1997-98 Årbog for Jysk Arkæologisk Selskab}

With summaries in English 
Redaktion: Hans Jorgen Madsen og Jesper Laursen

\section{Omslag: Louise Hilmar}

Tilrettelagning: Narayana Press

Tryk: Narayana Press

Skrift: Bembo 12/13

Papir: $115 \mathrm{~g}$ Arctic Silk

Copyright (C) 1998 by Jysk Arkaologisk Selskab

ISBN 87-7288-597-1

ISSN 0454-6245 


\section{Indhold/Contents}

Hans Jorgen Madsen og Else Roesdahl: Olaf Olsen 70 år $\ldots \ldots \ldots \ldots \ldots \ldots \ldots \ldots$

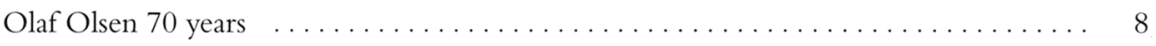

Søren H.Andersen: En mønstret pragtøkse fra ældre Ertebølletid $\ldots \ldots \ldots \ldots \ldots \ldots$.

A Magnificent ornamented axe from the Early

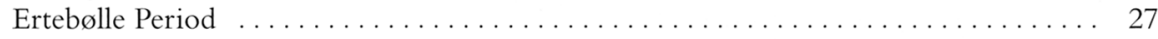

Henrik Skousen: Rønbjerg Strandvolde - en kystboplads

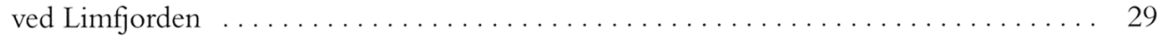

Rønbjerg Strandvolde - a coastal settlement by the Limfjord $\ldots \ldots \ldots \ldots \ldots \ldots \ldots 71$

Lisbeth Christensen: Vandet skole - en ældre romertidsgrav med

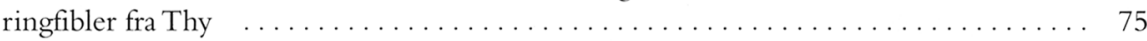

An Early Roman Iron Age grave with ring brooches from

Vandet School in Thy ........................................ 103

Bjarne Henning Nielsen: Jernalderfund fra Egådalen . . . . . . . . . . . . . . . . . 105

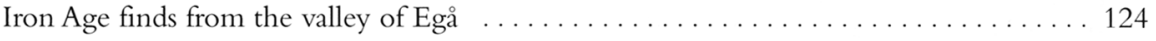

Elisabeth Barfod Carlsen: Et smykke i slægt med guldbrakteaterne $\ldots \ldots \ldots \ldots \ldots \ldots . \ldots 127$

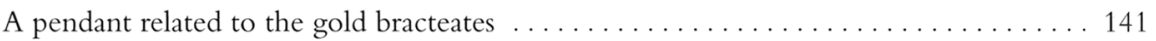

Claus Feveile, Stig Jensen og Kaare Lund Rasmussen: Produktion

af drejet keramik i Ribeområdet i sen yngre germansk jernalder $\ldots \ldots \ldots \ldots \ldots \ldots 143$

The production of thrown pottery in the Ribe area towards

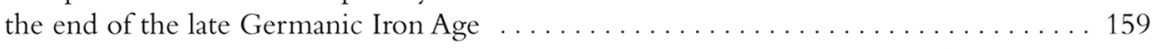

Ole Crumlin-Pedersen: Skibsfundene fra Hedeby $\ldots \ldots \ldots \ldots \ldots \ldots \ldots \ldots$

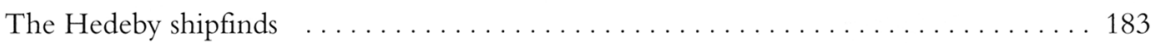

Anne Pedersen: Bidselbeslag fra Bøgeskov Strand . . . . . . . . . . . . . . . . . . . 185

A Harness Cheek-piece from Bøgeskov Strand ....................... 194

Bente Holmberg og Jan Skamby Madsen: Da kom en snekke ... . . . . . . . . . . . . . 197

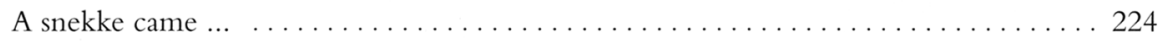

Hans Skov: Udgravningerne i Århus Midtby 1994-97 . . . . . . . . . . . . . . . . 227

The excavations in the centre of Aarhus 1994-97 . . . . . . . . . . . . . . . . . 292

Thomas Bertelsen: Kirketage ........................................ 295

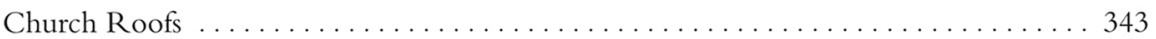

Anmeldelser .................................................. 347

Jysk Arkæologisk Selskab 1997 . . . . . . . . . . . . . . . . . . . . . . . . 369

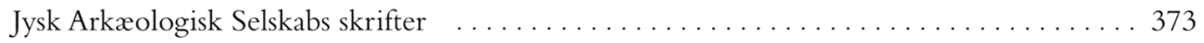




\title{
Skibsfundene fra Hedeby
}

\author{
Af Ole Crumlin-Pedersen
}

I 1997 kunne Hedeby-forskningen fejre jubilæum, idet det da var 100 år siden Sophus Müller i bogen Vor Oldtid pegede på området inden for halvkredsvolden ved Haddebyer Noor syd for Slesvig by som det sandsynlige sted for vikingetidsbyen i grænselandet mellem de danske stammer og sakserne, friserne og de slaviske abodriter - den by som samtidige kilder benævner Haiðaby eller Sliesthorp/Sleswic, alt efter om de citerer nordiske eller saksiske kilder.

Dette blev få år senere efterprøvet af de tyske arkæologer Splieth og Knorr fra Museum vaterländischer Alterthümer i Kiel, og siden da har ikke blot Hedeby, men også Danevirke og Slesvigs middelalderlige bykerne som bekendt været genstand for en lang række arkæologiske undersøgelser under ledelse af blandt andre tyskerne Herbert Jankuhn, Kurt Schietzel og Volker Vogel, af danskerne Olfert Voss og Hellmuth Andersen, samt mange flere.

I kraft af disse undersøgelser er det i dag muligt at tegne et detaljeret billede af denne grænseregions befæestningsværker og dobbeltbyen Hedeby/Slesvig. Vi ved idag meget om bebyggelsernes placering og udformning og kan i detaljer studere handel og håndværk, som disse aktiviteter tegner sig i fundene. Blandt gravene udmærker sig særligt den store bådkammergrav, som Friedrich Knorr udgravede allerede i 1908, ${ }^{1}$ og som Michael Müller-Wille ${ }^{2}$ og senest Egon Wamers ${ }^{3}$ har behandlet udførligt. Udfra gravpladsernes vidnesbyrd har Heiko Steuer givet sit bud på den vekslende etniske sammensætning af befolkningen i Hedeby. ${ }^{4}$ Hartvig Lüdtke har med sine keramik-studier klarlagt hovedtrækkene i kronologien ved overførslen af aktiviteterne i løbet af 1000-tallet fra den plads, vi kalder Hedeby til det sted, der nu hedder Schleswig. ${ }^{5}$ Nyere undersøgelser i Hedebys opland har kastet lys over de landsbyer, der er skudt op i nærheden for at forsyne byen med levnedsmidler og byggematerialer, ${ }^{6}$ og det botaniske materiale er analyseret og præsenteret af Behre som en afspejling af bebyggelsens indvirkning på det stedlige økosystem. ${ }^{7}$ Forbindelserne vestpå til Hollingstedt er behandlet af Lüdtke ${ }^{8}$ og senest af Klaus Brandt i nye udgravninger.

Talrige andre forskere har făet adgang til at arbejde inden for deres specialer med materiale fra disse udgravninger, og dette har ført til større og mindre bidrag til de skriftserier, der med stor konsekvens er udgivet fra 


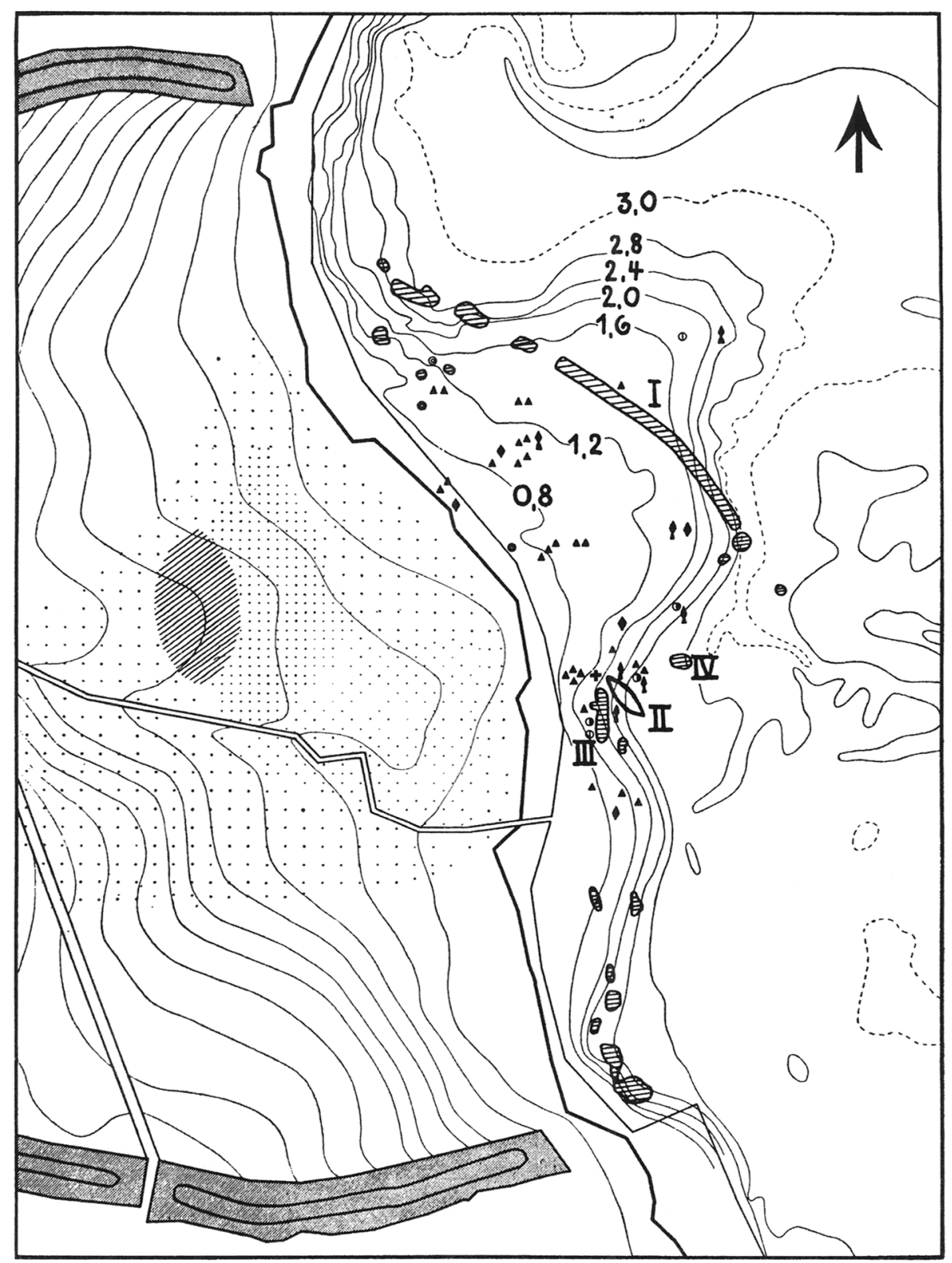

Fig. 1. Hedebys havneområde. Fundkort fra dykkerundersøgelsen i 1953. (Efter Hingst \& Kersten 1959).

The harbour area of Hedeby with finds from the investigations by a diver in 1953 . 
Archäologisches Landesmuseum, Schleswig. ${ }^{9}$ Igennem årene har Jankuhn udgivet sin sammenfatning af denne forskning i bogen Haithabu. Ein Handelsplatz der Wikingerzeit, hvis sidste udgave fra 1986 var 8. stærkt omarbejdede version, men fra dansk side har det været småt med sammenfattende fremstillinger af denne vigtige vikingetidsbys historie.

På denne scene har jeg også haft min gang igennem en lang årrække. Mit allerførste møde med Hedebyforskningen var i 1953, da jeg som 18årig knægt hørte en transmission i Statsradiofonien med en dykker, der på foranledning af arkæologerne Hingst og Kersten afsøgte bunden af noret ud for Hedeby og undervejs stødte på vraget af et vikingeskib (fig. 1). ${ }^{7}$ Måske var det netop denne udsendelse, der vakte dén interesse for den maritime arkæologi, der aldrig senere har forladt mig. I hvert fald henvendte jeg mig allerede i 1956 for at fă nærmere oplysninger om det bjergede som referencemateriale til de skibsdele, der var fundet ved Skuldelev i Roskilde Fjord, og jeg blev ved den lejlighed indbudt til at studere det fundne.

Da Kurt Schietzel i 1963 overtog ansvaret for Hedeby-udgravningerne, ønskede han også at følge op på skibsfundet, og to år senere blev der indgået den aftale med Nationalmuseet, at jeg i fornødent omfang kunne stilles til rådighed herfor. Det førte i første omgang til, at 1953-fundet blev publiceret i $1969 .{ }^{11}$ Denne publikation skulle komme til at spille en vigtig rolle $\mathrm{i}$ bestræbelserne på at skaffe de fornødne midler til ikke blot at udgrave og hæve skibet, men også til at opbygge et konserveringsværksted på Gottorp Slot og et museum ude ved halvkredsvolden, hvori man kunne udstille skibet og andre fund fra Hedeby.

Det var et stort læs at trække for et vragfund, der tydeligvis var udbrændt og stærkt beskadiget, men begrebet vikingeskib fængede, og efter adskillige års forberedelser kunne udgravningen gennemføres i 1979 indenfor en spunsvæg, der omsluttede fundstedet og herfra rakte ind til tørt land i et smalt bælte. Hermed var udgravningen af skibet sikret, og dette gav som en tillægsgevinst mulighed for at lave en systematisk udgravning af et udsnit af havneområdet med kontakt til strandkanten. Resultaterne var her så fine, at der blev bevilliget midler til året efter at udvide arealet på begge sider af den første udgravning. På denne måde blev et område på ca. $2000 \mathrm{~m}^{2}$ af vikingetidens havn nærmere undersøgt $\mathrm{i}$ årene 1979-80 (fig. 2).

Mens dette arbejde fandt sted, gennemførte geofysikeren Stümpel og hans folk en minutiøs seismisk kortlægning af hele havneområdet, hvorved de kunne supplere og korrigere de iagttagelser om fund af skibsbroer, havnepalisader og løsfund, som dykkeren havde gjort i 1953. ${ }^{12}$ De sendte selv dykkere ned på bunden på de steder, hvor de havde fået et særligt stærkt eller særpræget ekko på deres udstyr, og det førte til en række nye fund. Disse rakte fra pælesætninger over en kirkeklokke til to 


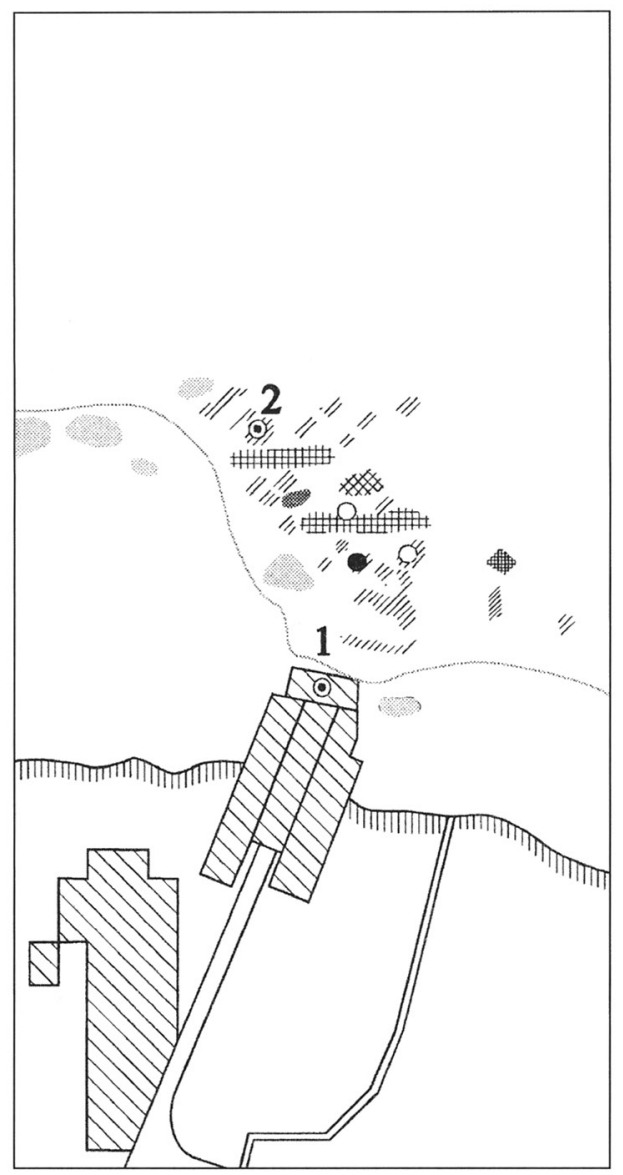

Fig. 2. Hedebys havneområde med de udgravede felter fra byudgravningerne i 1960erne og fra havneudgravningen i 1979-80 (skraveret). Nr. 1 og 2 er fundstederne for vragene Hedeby 1 og 2 . Strukturer fra havnebefæstningen, lokaliseret af dykkeren i 1953 og ved de seismiske undersøgelser omkr. 1980, er markeret. (Efter Crumlin-Pedersen 1997).

The harbour area of Hedeby with the excavated areas from the town excavations in the 1960 's and from the harbour excavation in 1979-80 (hatched). Nos. 1 and 2 are the findspots for the wrecks Hedeby 1 and 2. Structural elements from the harbour defence system recorded by the diver in 1953 and by the seismic investigations around 1980 are indicated.

stammebåde og yderligere to vrag af vikingetidsskibe, hvoraf dele blev bjærget af geofysikerholdets dykkere.

Hermed var der rigeligt materiale for mig at arbejde med til publicering af skibsfundene fra Hedeby, og det suppleredes yderligere med adskillige skibsdele, der i de efterfølgende år blev udgravet i Schleswigs havneområde fra 1000- og 1100-tallet. Det blev til adskillige års arbejde, inden det var gennemarbejdet og kunne udgives i februar 1997 som forste arkæologiske bind i den engelsksprogede skibsarkæologiske monografiserie Ships \& Boats of the North, i dette tilfælde udgivet i et samarbejde mellem Schleswig og Roskilde. ${ }^{13}$

Fra Hedeby/Schleswig var det materiale, som jeg kunne arbejde med, naturligvis forst og fremmest de tre vrag og den tidligere udgravede bådkammergrav, men dertil kom et omfattende materiale af løsdele fra skibe, dels $\mathrm{i}$ form af genanvendt tømmer fra broer og huse, dels kasserede eller tabte dele af skibenes og bådenes rig og øvrige udrustning. Jeg inddrog tillige de fundne bådmodeller og Hedeby-mønter med skibsmotiv, 

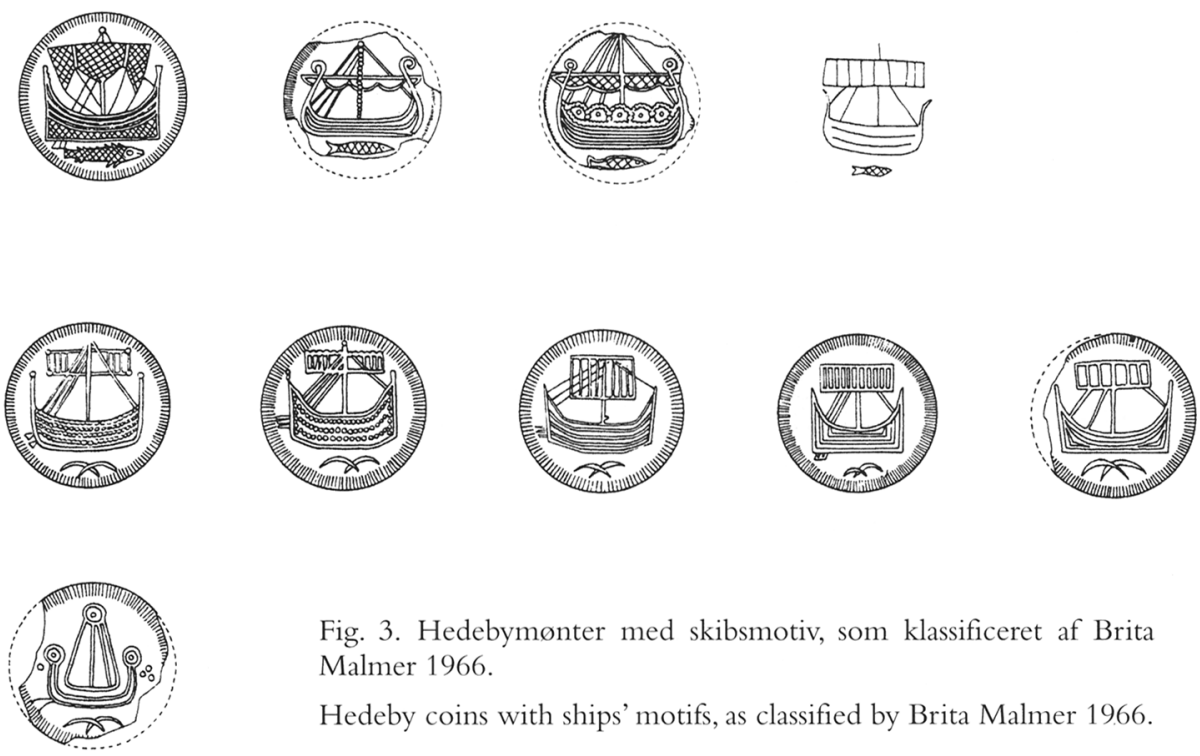

Fig. 3. Hedebymønter med skibsmotiv, som klassificeret af Brita Malmer 1966.

Hedeby coins with ships' motifs, as classified by Brita Malmer 19.66.

mens stammebådene blev behandlet af Christian Hirte, der tidligere havde arbejdet med fund af denne bådtype i lokalområdet.

Til gengæld var det uden for mit mandat at bearbejde havnens topografiske forhold, hvortil de fundne skibsbroer kan bidrage med vigtige nye oplysninger, idet Kurt Schietzel agter at fremlægge undersøgelserne af dette materiale.Visse hovedtræk måtte jeg dog gå ind på i mit arbejde for at kunne tolke fundomstændighederne nærmere. Men selv med denne begrænsning var der nok at tage fat på. Jeg skal i denne artikel redegøre for enkelte af resultaterne af bearbejdningen af dette skibsfundsmateriale, idet jeg har bestræbt mig på at vælge eksempler, der supplerer de hidtidige synsvinkler, der har været anlagt på materialet i Hedeby-forskningen.

Den første materialegruppe, jeg skal drøfte, er Hedeby-mønterne med skibsmotiver. De er fundet i Birkas grave nær Stockholm og iøvrigt spredt i andre dele af Skandinavien, men endnu aldrig i Hedeby. Ikke desto mindre har den svenske numismatiker Brita Malmer i 1966 kunnet påvise, at de med stor sandsynlighed er udstedt i Danmark og mest sandsynligt i Hedeby i første fjerdedel af 800-tallet (fig. 3). ${ }^{14}$ Hendes norske kollega Kolbjørn Skaare har søgt forbillederne for disse mønter med skibsmotiver i nogle frankiske mønter slået i Dorestad og Quentowic i samme periode, ${ }^{15}$ og arkæologerne Arne Emil Christensen og Detlev Ellmers har søgt at udlæse detaljer om 800-tallets skibes skrog og rig fra mønterne. ${ }^{16,17}$ Der er da også ganske rigtigt fundet en af Dorestad-møn- 


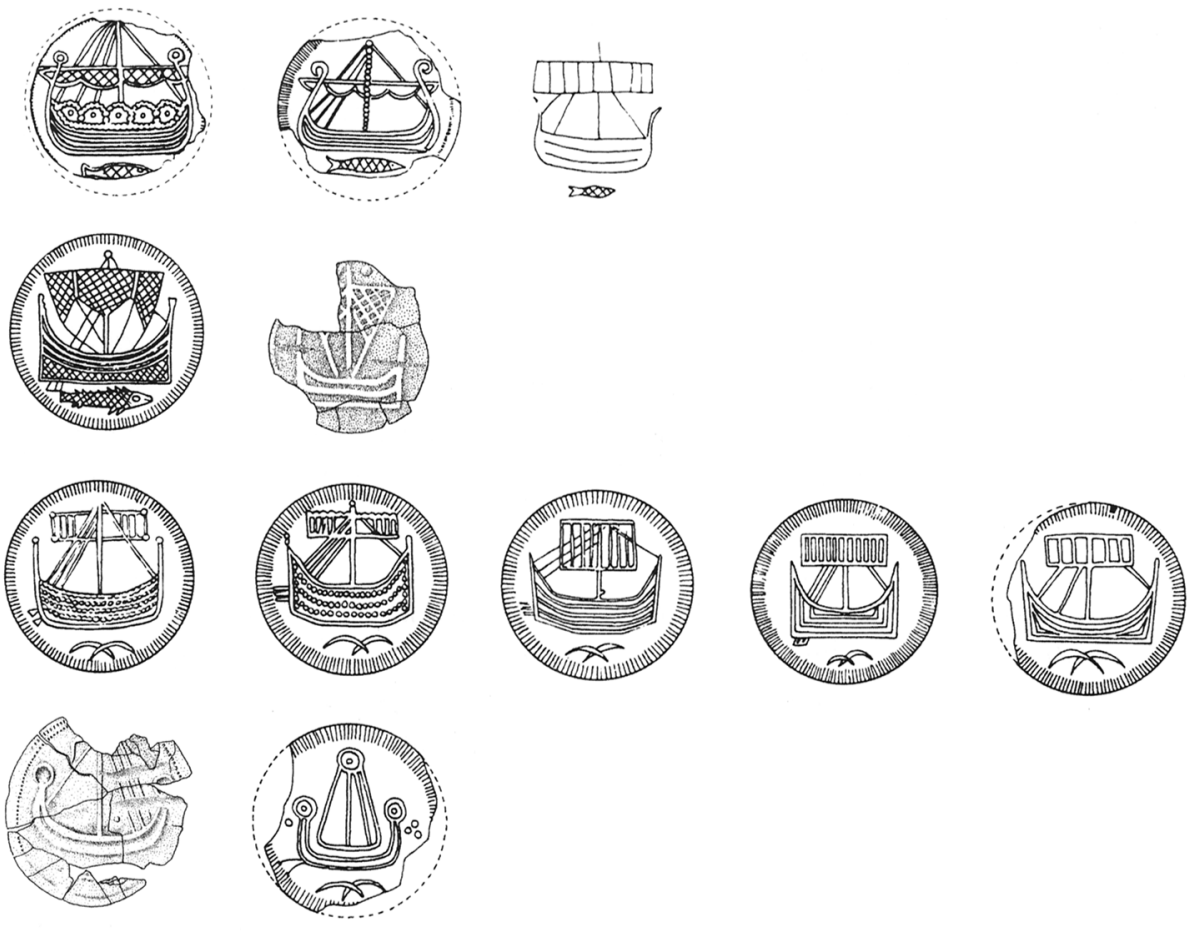

Fig. 4. Efter flere nyfund af Hedebymønter med skibsmotiv er disse blevet ny-klassificeret i fire grupper. (Efter Crumlin-Pedersen 1997).

The Hedeby coins with ships' motifs have been reclassified in four groups, including the newly found coins.

terne med skibsmotiv i en grav i Hedeby. Problemet med tolkningen af skibsmotiverne på Hedebymønterne som efterligninger af de frankiske mønter ligger dog deri, at skibene på Hedebymønterne er langt mere præcist og detailrigt gengivet, end tilfældet er for de stærkt stiliserede skibe fra Dorestad, og at de iøvrigt slet ikke ligner disse. I en kopieringsproces går det jo gerne den modsatte vej, at originalens detaljer udviskes eller forvanskes, efterhånden som de kopieres gang på gang. Siden 1966 er der kommet enkelte nyfund af Hedebymønter med skibsmotiver, som giver anledning til en revision af den hidtidige inddeling (fig. 4). ${ }^{18}$

Det seneste, perspektivrige bud på tolkning af de billedrige Hedebymønter, som den svenske arkæolog Björn Varenius er kommet med, tager sit udgangspunkt i spillet om magten mellem danskekongen og Frankerriget i den tidlige del af 800-tallet. ${ }^{19}$ Kong Godfred stillede som bekendt et effektivt værn op ved Danevirke mod Karl den Stores tropper, men efter hans død i 810 blev der strid mellem Harald Klak, der i 826 lod sig døbe og som førte sig frem i Danmark og Sydnorge med kristen mission, 
og Godfredsønnerne, der var i opposition hertil.Varenius ser de tidligste Hedebymønter, der er uden billeder, men med forvanskede indskrifter der kopierer Dorestadmønter, som udtryk for Harald Klaks frankervenlige politik, idet han hermed efterligner de frankiske herskeres symbol for deres kontrol over handelspladsen, i dette tilfælde Hedeby. Efter Harald Klaks fordrivelse i 827 markerer Godfredsønnerne så deres magtovertagelse ved som kontrast at udstede de billedrige Hedebymønter med motiver, herunder skibe, der har deres klare rødder i den nordiske mytologiske verden og netop ikke i kristne frankiske forbilleder.

Hertil kan vi så føje, at skibet som motiv i den nordiske vikingetidsmytologi formentlig i de fleste scener skal ses som en gengivelse af Skiblaðnir, Frøjs lykkebringende attribut, det magiske skib der altid har medvind og som knytter tråde tilbage til gamle forestillinger om frugtbarhedsgudens årlige genkomst over havet. ${ }^{20}$ Denne myte om et slægtskab med frugtbarhedsguderne indgår som et vigtigt element $\mathrm{i}$ de nordiske kongeslægters legitimitet, som det hos os afspejles i myten om kong Skjold, der som barn ankommer til sit land i sit skib, liggende på et kornneg, og hvis ligfærd efter endt, velsignelsesrig gerning påny går over havet.

Hvilken betydning har da alt dette for en skibsarkæolog, der vil bruge mønterne til at blive klog på vikingskibenes udseende? Det har den vigtige erkendelse til følge, at vi bliver mindet om, at skibsafbildningerne ikke nødvendigvis efter deres natur er naturalistiske gengivelser af datidens skibe, men sindbilleder af mytisk karakter, formentlig med en forankring i processioner o.l., hvori skibe som Osebergskibet kan have indgået. Sådanne 'ikoner' med symbolsk indhold kan have mange realistiske træk, men må ikke tages som fuldgyldige udtryk for, hvordan hverdagens skibe så ud i datiden.

Dette fører os så over til skibsfundene. De har jo sejlet og tjent et eller flere praktiske formål, der lader sig udlæse af skibenes form og indretning. Her danner gravskibene en interessant mellemgruppe, for de indgår jo også i en kultisk sammenhæng. Parallelt med situationen for skibsbillederne anser jeg skibene og bådene $\mathrm{i}$ gravene som gravgaver til personer med tilknytning til frugtbarhedskulten, Vanekulten. ${ }^{21}$ For kongeætten bliver båden eller skibet symbol på deres slægts ret til magten. I de perioder og områder, hvor de gamle trosforestillinger og den nye kristendom mødtes i en magtkamp, bliver dette symbol ekstra stærkt markeret med et stort skib som gravgave til kongelige personer af den gamle tro. Det ser vi i det tidlige 600-tal i East Anglia med de store skibsgrave ved Sutton $\mathrm{Hoo}^{22}$ - netop i brydningstiden omkring indførelsen af kristendommen i denne del af England - og to hundrede år senere i Sydnorge med Oseberggraven, der er anlagt ca. 834 og dermed i tid falder sammen med Harald Klaks missionsfremstød i denne region.

I denne sammenhæng kan det synes paradoksalt, at netop bådkammer- 


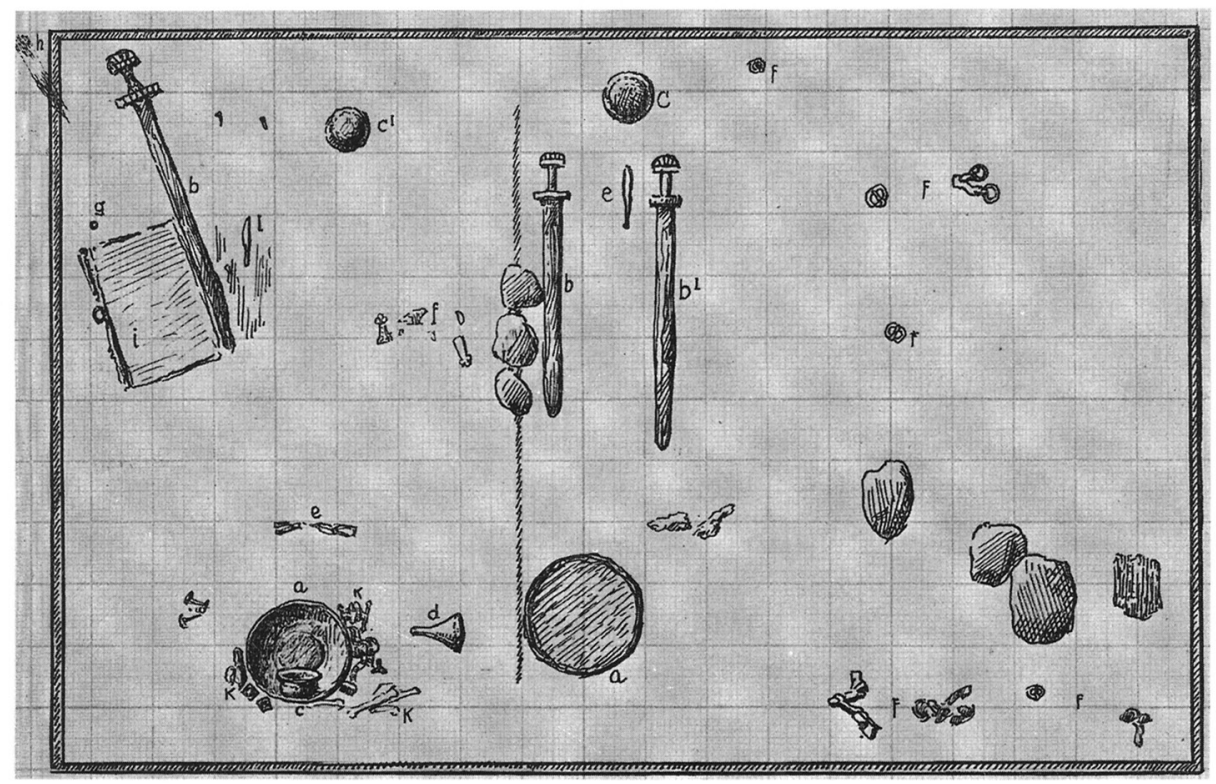

Fig. 5. Gravkammeret i Hedeby bådkammergrav. (Efter Knorr 1911).

The burial chamber from the Hedeby boat-chamber grave.

graven fra Hedeby, hvor en kammergrav for tre personer er overlejret af et skib, der af den tyske arkæolog Egon Wamers for nylig er blevet tolket som Harald Klaks grav (fig. 5). ${ }^{23}$ Baggrunden herfor er Detlev Ellmers' påvisning af, at de gravsatte ud fra gravgaverne ser ud til at have været en højtstående person, formentlig af kongelig byrd, og dennes marskal og mundskænk. ${ }^{24}$ Dermed knyttes forbindelsen til det frankiske hofceremoniel, og de kostbare sværd og rige gravgaver svarer ganske til, hvad Harald Klak modtog som dåbsgaver af Ludvig den Fromme og dennes familie ved hans dåb i Ingelheim i 826 ifølge en bevaret samtidig kilde. Denne interessante hypotese lader flere spørgsmål stå åbne, men blandingen af en hedensk gravskik og gravgaver af kristen oprindelse finder vi også i Sutton Hoo graven, og er altså ikke et bevis herimod. Hvis graven virkelig skulle være Harald Klaks, kan skibet i graven meget vel være hans efterkommeres forsøg på at markere, at slægten ikke havde accepteret den nye religion, men netop understregede ættens forbindelse til den gamle kult, der da også fortsat rådede i Danmark i hundrede år.

Hvad skibet i graven angår, er der ikke meget tilbage efter udgravningen i 1908, blot nogle jernnagler og en udgravningsplan, der antyder et skib af karakter som Ladby- og Skuldelev 5 -skibene. ${ }^{25}$ Det bliver vi ikke meget klogere på vikingetidens skibsbyggeri af. Så er der betydeligt mere at hente i de tre vrag fra havnen. Med dem har vi bevæget os op til Hedebys seneste fase i slutningen af 900-tallet og begyndelsen af 1000-tallet, 
hvor havnen var udbygget til bristepunktet med skibsbroer og havnepalisader, og hvor overflytningen til Schleswig var begyndt.

Lad os af de tre skibe begynde med det midterste, Hedeby $2 .{ }^{26}$ Det blev fundet af geofysikerne, der tog betydelige dele af vraget op i småstykker uden nærmere at redegøre for fundforholdene. Det betyder, at jeg har måttet lægge puslespil uden forlæg og med tilfældigt udvalgte brudstykker af helheden. Resultatet blev, at hverken fartøjets størrelse eller form har kunnet nærmere bestemmes. Det bedste skøn lyder på, at der er tale om et relativt robust bygget brugsfartøj på mellem 9 og 12 meters længde. Det interessante ved denne storbåd er detaljerne, der kan aflæses i valg af byggematerialer og byggeteknik. Båden er klinkbygget med et bundparti i egeplanker, samlet med jernklinknagler, mens siderne består af planker af bøg og fyr, der er samlet indbyrdes med små trænagler. Spanterne er tydeligvis genbrug fra et andet fartøj, og det hele giver et så blandet indtryk, at jeg først troede, der var tale om to forskellige fartøjer. Det er imidlertid ikke tilfældet, det er to forskellige byggetraditioner, der er blandet i samme båd: den vestslaviske med brug af de små trænagler i bordene og den nordiske med jernnaglerne.

Sammenholder vi dette fund med andre skibsfund fra Norden og Østersøens sydkyst (fig.6), fremtræder der et klart mønster, hvor trænag-

Fig. 6. Fordeling af skibsfund fra perioden 600-1200 med markering af bordenes indbyrdes samling og tætning. (Efter Crumlin-Pedersen 1997).

The distribution of shipfinds dating to AD 600-1200, with indications of the principles of fastening and caulking of the planking.

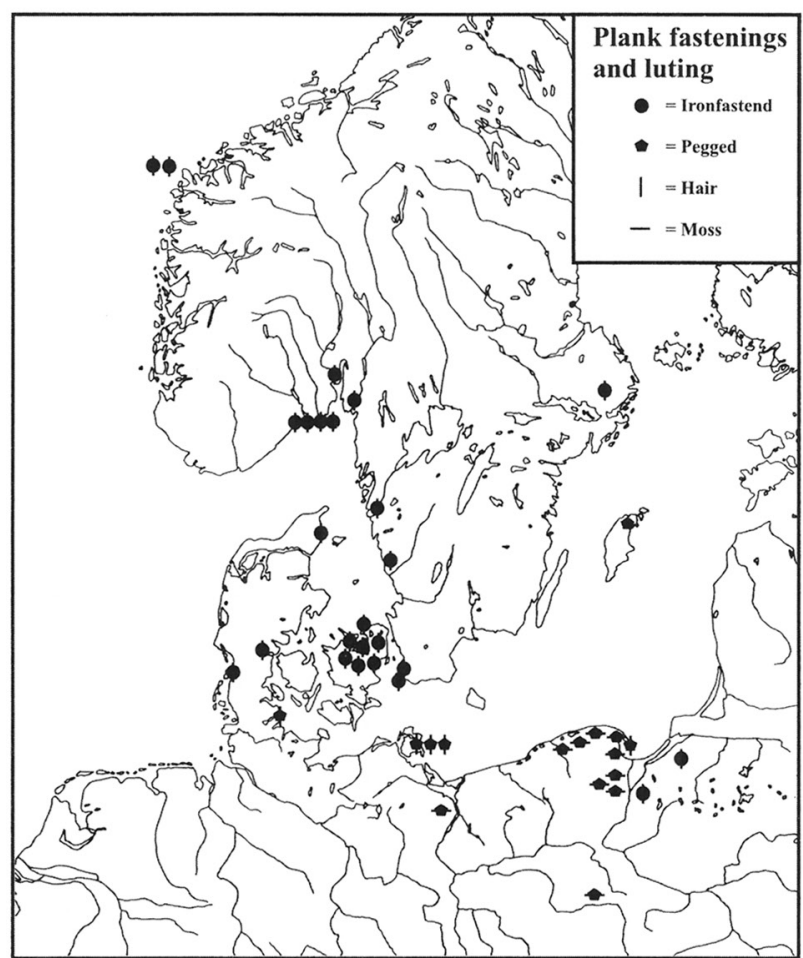


lede bord med mos-kalfatring er karakteristiske træk i det vendiske bådebyggeri, der iøvrigt i opbygningen af skroget stort set følger de samme principper som i Norden. Jo længere vestover mod Hedeby vi kommer, des stærkere slår de nordiske træk imidlertid igennem, med Hedeby $2-$ fartøjet som det mest udprægede eksempel på vendisk bådebyggeri med dansk inspiration.

De egematerialer, der er brugt i båden, er øjensynligt fældet i Slesvigområdet i slutningen af 900-tallet, og den er altså bygget lokalt, utvivlsomt af en vendisk bådebygger, der imidlertid ikke har haft tilstrækkelig adgang til nyt egetømmer til planker og spanter. Derfor har han måttet tage til takke med at genbruge spanterne fra en gammel båd, der er blevet ophugget, og til de øvre planker har han kun haft adgang til bøg og fyr. Af disse træsorter er bøgetræet meget udsat for at blive ødelagt af råd, og der må derfor have været tungtvejende grunde til at fravælge egetræet.

Vi ser den samme tendens i de to fundne stammebåde, hvoraf den ene er lavet af eg, mens den anden er af bøg. ${ }^{27}$ De er begge dateret til vikingetiden, og bøgebåden er det ældste eksempel på stammebåde af dette materiale, der i middelalderen fortrængte egetræet til dette brug indenfor dansk område. Som påpeget af Christian Hirte kan dette hænge sammen med, at der allerede i vikingetiden har været udstedt regler for, hvem der måtte hente materialer i skoven af særlig værdifuld karakter. ${ }^{28}$ Sådanne skovforordninger kendes fra Karl den Stores Capitulare de villis fra ca. 800 , og de kan være kopieret herfra til lokal brug i Hedebyområdet, hvor den oprindelige skov med dominans af eg i løbet af vikingetiden blev udtyndet og delvis erstattet af en skov, hvor bøg dominerede.Vi skal senere vende tilbage til denne hypotese.

Går vi herfra til vraget Hedeby 3, møder vi et skib af en helt anden karakter, et stort velskabt fragtskib, bygget lokalt omkring 1025 og klart tilhørende den danske byggetradition. ${ }^{29}$ Også dette skib er lokaliseret af geofysikerne, og de har bjærget vigtige dele heraf, i dette tilfælde dog under arkæologisk kontrol, så stykkernes indbyrdes position er kendt. Det drejer sig spanter, knæ og kølsvin, der har muliggjort en rimeligt sikker rekonstruktion af skibets karakter og størrelse (fig. 7). Hedeby 3-skibet har været et havgående fragtskib, måske af knorr-typen og nært beslægtet med det noget mindre Skuldelev 1-skib. ${ }^{30}$ Skibet har været ca. $22 \mathrm{~m}$ langt og 6,25 m bredt med en lasteevne på ca. 60 tons (fig. 8). Også dette skib er bygget med en blanding af egetræ og andre træsorter, dog ikke bøg, som vidnesbyrd om, at mangelen på godt egetræ til skibsbygningsbrug også var følelig for de danske skibsbyggere på stedet.

Med en så stor lasteevne får vi et indtryk af omfanget af de transporter, som skibet er bygget for. Det er ikke sandsynligt, det er bygget til bøndernes egen fragt af levnedsmidler til byen; hertil er snarere anvendt mindre skuder af størrelse som Skuldelev 3-skibet på 4-5 tons lasteevne. ${ }^{31}$ 


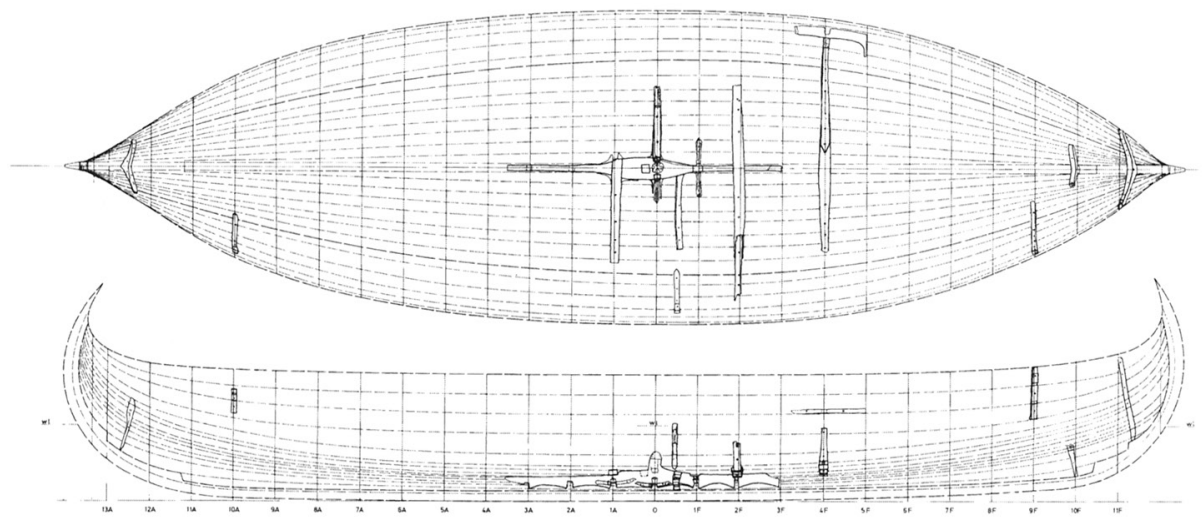

Fig. 7. Fra Hedeby 3-skibet er bjærget mange enkeltdele af samme karakter som i Skuldelev 1, men Hedeby 3 har været større end dette, med en oprindelig længde på ca. 22 m. (Efter Crumlin-Pedersen 1997).

Several parts of the Hedeby 3-ship have been raised, which show close similarity to the Skuldelev 1-ship. The Hedeby 3-ship, however, was larger, with an original length of c. $22 \mathrm{~m}$.

Hedeby 3-skibet kunne derimod have været bestemt til at indsamle bøndernes afgifter af korn og andre afgrøder til kongens forråd i tilfæelde af, at et sådant afgiftssystem allerede blev praktiseret tidligt i 1000-tallet. Mere sandsynligt er det dog, at der er tale om et handelsskib til fart på fjerne destinationer i Østersø- og Nordsøområdet. Det er tankevækkende at prøve at sætte navn og tal på de potentielt mulige varer fra de forskellige havne - der er trods alt langt til 60 tons med de varer, man normalt forbinder med handel ved vikingetidens slutning.

En god parallel til dette store, lokalt byggede fragtskib fra Hedeby/Schleswig finder vi halvandet århundrede senere et uventet sted, nemlig i Thomas af Canterbury's helgenkrønike fra ca. 1175. En sådan hagiografisk tekst skal tjene til at fremhæve vedkommende persons gode og hellige gerninger og skal derfor tages med mere end et gran salt. I dette tilfælde er der imidlertid meget, der taler for, at der er en kærne af kendsgerninger bag historien. Denne lyder som følger. ${ }^{32}$

"En rig mand i Danmark, borger $i$ byen Slesvig, fik med stor bekostning bygget er stort skib. Og landets konge besluttede at gå $i$ kompagniskab og fa del $i$ indtjeningen. Og da han havde skaffet halvdelen af kapitalen, fik han en tilsvarende ejerpart. Da skibet var bygget og klar til søsatningen, kunne man ikke flytte det på grund af skrogets store storrelse, og krafterne var spildt, selv når man konstant skubbede og havde ruller nedenunder og tove til at trakke i. Det blev da klart for enhver, at man måtte ophugge skibet på stedet. For at undgå et sådant spild af indsatser og økonomiske udgifter besluttede den fortvivlede 


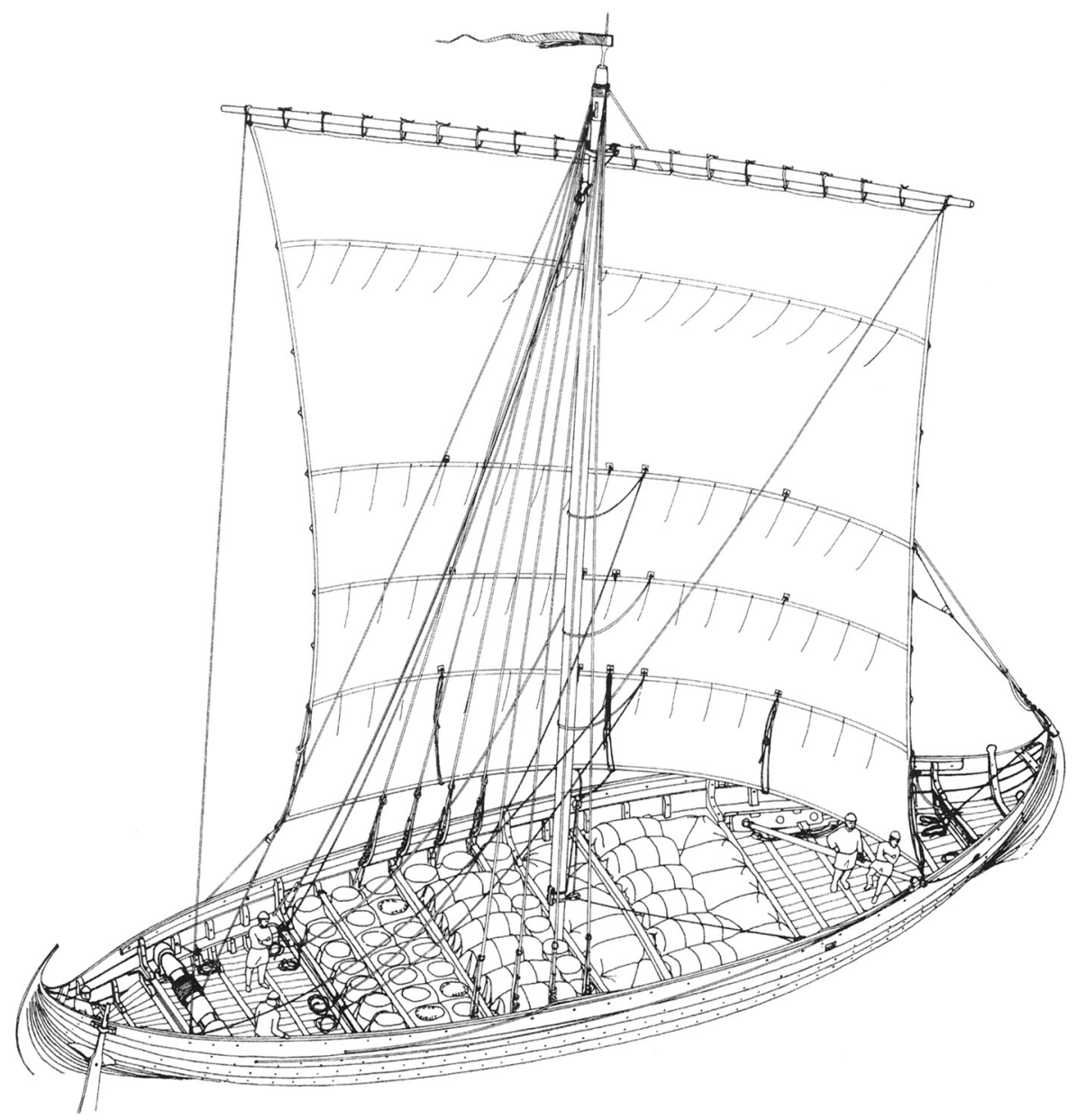

Fig. 8. Hedeby 3-skibet, hypotetisk rekonstruktion. (Efter Crumlin-Pedersen 1997).

Hypothetical reconstruction of the Hedeby 3-ship.

ejer af skibet at påkalde den nye martyr Thomas af Canterbury's hjolp. Han vendte sig mod ham med ordene: "Hvis du kan bringe skibet ud på dybt vand, Martyr, lover jeg dig hundrede pund voks fra hver af skibets rejser". Ved pres alene med de bare hoender og langt mindre kraft end for, gled skibet nu over en glat flade $i$ et let lob ud i bolgerne. Og den forpligtelse, der blev indgået med loftet, er overholdt indtil nu."

Her er altså tale om lokal bygning af et storskib til et partsrederi af kongen og en lokal storkøbmand, beregnet til en rute, hvorfra man hentede voks hjem i større mængder, antagelig i den østlige ende af Østersøen. Om skibets typenavn, opbygning og lasteevne hører vi intet, men den 


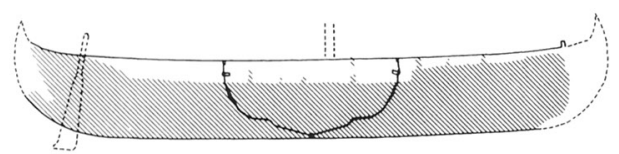

SKULDELEV 1

c. 1000

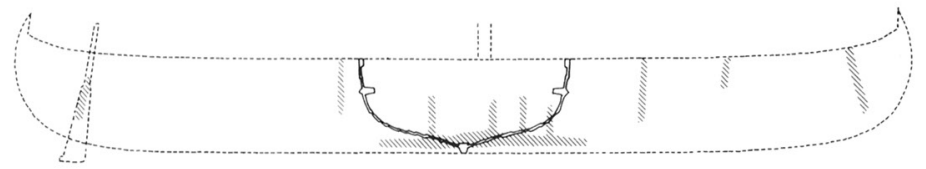

HEDEBY 3

11 th century

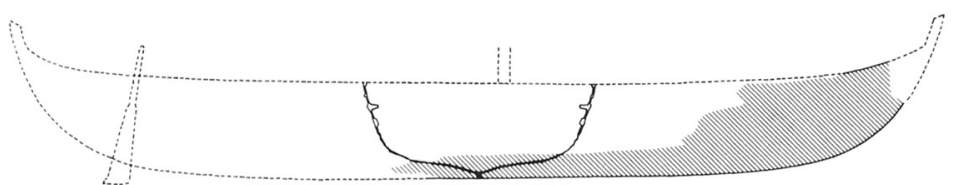

LYNAES 1

c. 1150
24 tons cargo

$16.3 \times 4.5 \times 21 \mathrm{~m}$

c. $25 \times 5.7 \times 2.5 \mathrm{~m}$

c. $25 \times 6 \times 2.5 \mathrm{~m}$
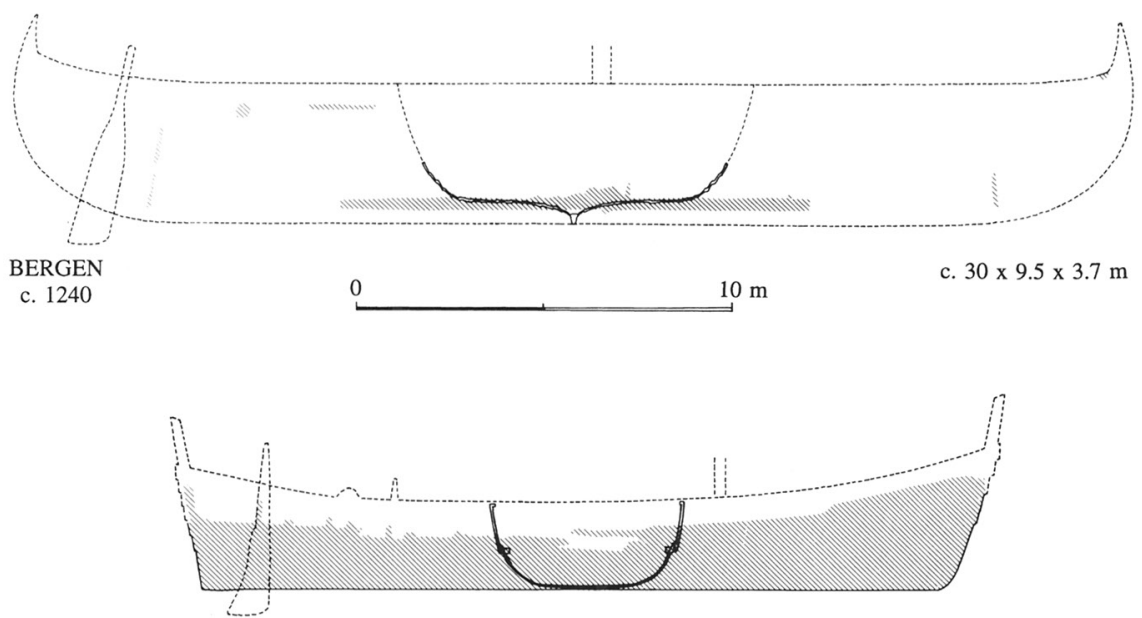

KOLLERUP

$1150-1200 \quad$ c. $20.1 \times 4.8 \times 2.2 \mathrm{~m}$

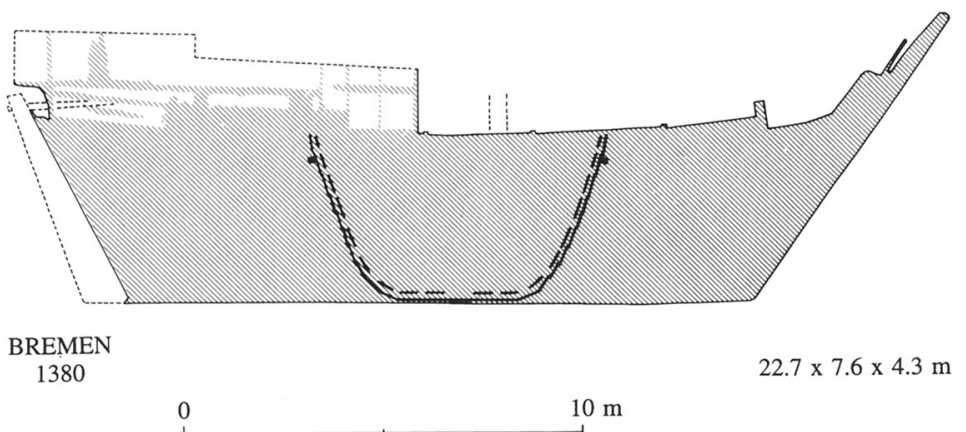

Fig. 9. Silhouetter af fragtskibsfund fra perioden 900-1400. De bevarede partier er markeret ved skravering.

Silhouettes of freighters from the period AD 900-1400. The preserved parts are shaded. 
tyske historiker Christian Radtke har antaget, at der var tale om en kogge, da man tidligere ikke har tiltroet vikingeskibstraditionen at kunne udvikles til bygning af store fragtskibe. ${ }^{33}$

Det véd vi i dag er forkert, for nu er store fragtskibe af nordisk type fra 1000-tallet til ind i 1200-tallet kendt gennem fundene fra Hedeby, Skuldelev, Roskilde, Lynæs og Bergen (fig. 9). ${ }^{34}$ I 1200-tallet udvikledes koggen under indflydelse af de nordiske og engelske skibe fra en flodskibskarakter til et egentligt havgående fragtskib, som det fremtræder $i$ fundene efter midten af 1200-tallet. Men så tidligt som ved midten af 1100-tallet, da hændelsen, som krøniken refererer til, må have fundet sted, har man i et kongeligt dansk miljø i Slesvig givetvis bygget udfra den danske byggetradition, videreført i udviklingen imod stadigt større skibe, som vi finder disse afspejlet i de nævnte skibsfund. Det har utvivlsomt adskillige gange givet problemer, når skibene ikke ville løbe af stabelen, blev for store til de hidtil anvendte anløbspladser, eller løb imod blinde skær, der ikke tidligere havde udgjort nogen fare for sejladsen. Der er omkostninger forbundet med at sprænge de hidtidige rammer, og inden for skibsbyggeriet kan det fă fatale følger. Derfor finder man her en sej fastholden ved kendte og vel afprøvede løsninger side om side med forsøg på at overføre nye elementer fra andre byggetraditioner, når skibsbyggerne blev stillet overfor kravet om at bygge stadigt større skibe.

Det sidste af de tre vrag fra Hedeby, vrag 1, giver os endnu et eksempel herpå..$^{35}$ Det er det vrag, som dykkeren havde fundet i 1953, og som var hovedemnet for udgravningen i 1979. Her er tale om resterne af et krigsskib, et langskib, der har været udsat for en voldsom brand ombord, og hvoraf kun dele af forskibet og kølen midtskibs er bevaret til i dag. Allerede ved publiceringen i 1969 kunne jeg udfra brandspor på de bevarede dele opstille flere mulige forklaringer herpå. Der kunne således være tale om en brand i havnekvarteret, der havde bredt sig til skibene, skibet kunne have været brugt som brander ved et angreb på havnen, eller det kunne være anvendt som gravskib ved en høvdingebegravelse, hvor den døde er sendt bort på et brændende skib, som vi kender det fra Bjovulfkvadet og Skjold-myten.

Ved udgravningen i 1979 fremstod brandsporene tydeligt som en forkulning af hele den bevarede del af bagbords skibsside og af enderne af bjælker og spanter, der har været i kontakt med denne del af skibet (fig. 10). Branden har tydeligvis fået sin næring primært af en mængde brandbare materialer, der har været opstablet indenbords og som er blevet antændt i hele skibets længde. Det udelukker tanken om, at skibet kan være blevet 'smittet' af en brand i havnen, eller at ilden kan være opstået ved et uheld ombord. Heller ikke gravskibsteorien rimer med det forhold, at skibet er fundet inde i havnen, lejret op ad to af skibsbroerne på 


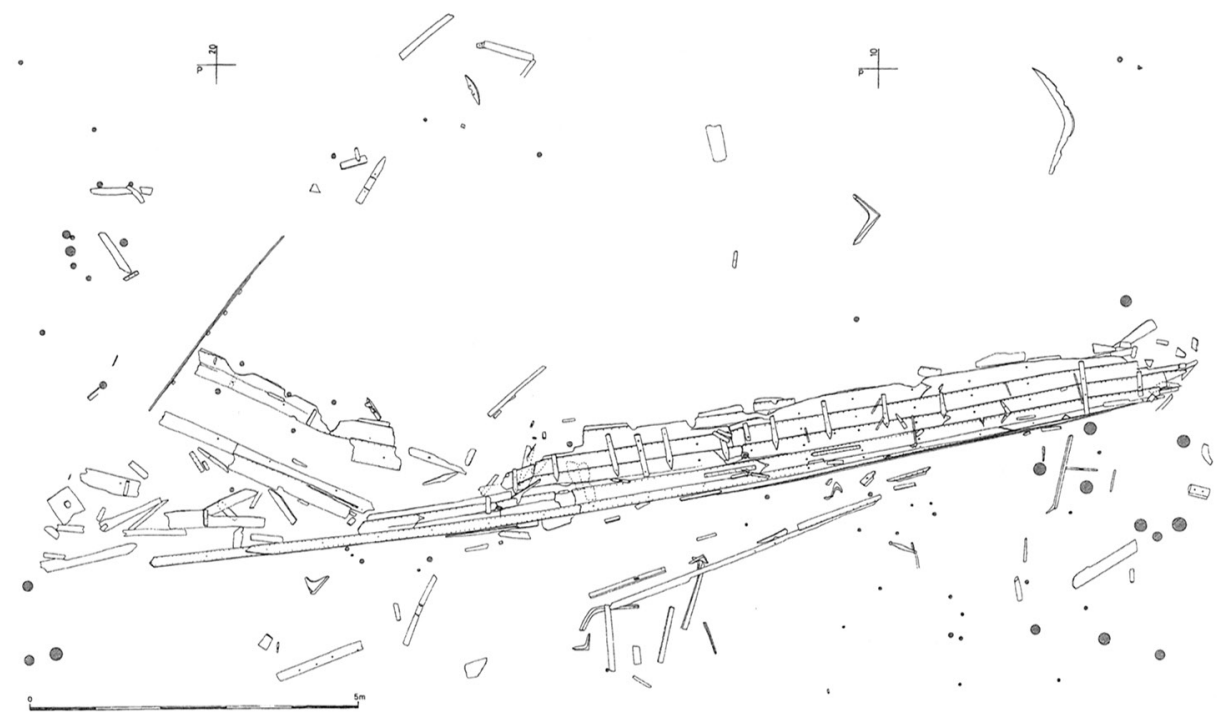

Fig. 10. Udgravningsplan af Hedeby 1-skibet. (Efter Crumlin-Pedersen 1997).

Excavation plan of the Hedeby 1-ship.

stedet. Tilbage er muligheden, at man har brugt dette skib ved et angreb på byen, hvorunder skibet er sendt brændende ind imod byens havnepalisade, hvorfra det så er drevet for østenvinden længere ind i havnen (fig. 11). Til støtte for denne tolkning gælder, at der i havnen også er fundet forkullede rester af svært tømmer, der kan have været dele af vagttårne ved indsejlingen. Vi skal straks vende tilbage til denne situation og forsøge at sætte den ind i en historisk sammenhæng.

Men først må vi se på skibet selv. Som nævnt er der tale om et krigsskib, men ikke et hvilketsomhelst af slagsen. Skibet er ifølge dendroanalysen bygget i årene umiddelbart efter 982 med en ganske usædvanlig høj kvalitet $\mathrm{i}$ håndværk og materialer, uden sidestykke blandt de danske vikingeskibsfund. Skibets planker er af eg i fornem kvalitet, og de enkelte længder er overalt samlet med nogle elegant udformede tungelaske, der ellers kun kendes fra enkelte af de største planker i Skuldelev 1-skibet. Indmaden, altså spanter, knæ, bjælker mv., er lavet af eg, el, ahorn og ask, mens alle fundne planker er spejlkløvet eg, tildels i længder på omkring og over 10 meter. ${ }^{36}$ Så store, spejlkløvede egeplanker kendes ikke fra noget andet fund, og de virker påfaldende i en periode, hvor skibsfundene ellers udviser tendens til stærkt faldende længde- og breddemål på plankerne og en stigende grad af genbrug af materialer fra ophuggede skibe.

Med denne fornemme kvalitet i konstruktionen, der tilmed er gentaget i de reparationer, der findes i skrogets plankeskal, må dette skib karak- 


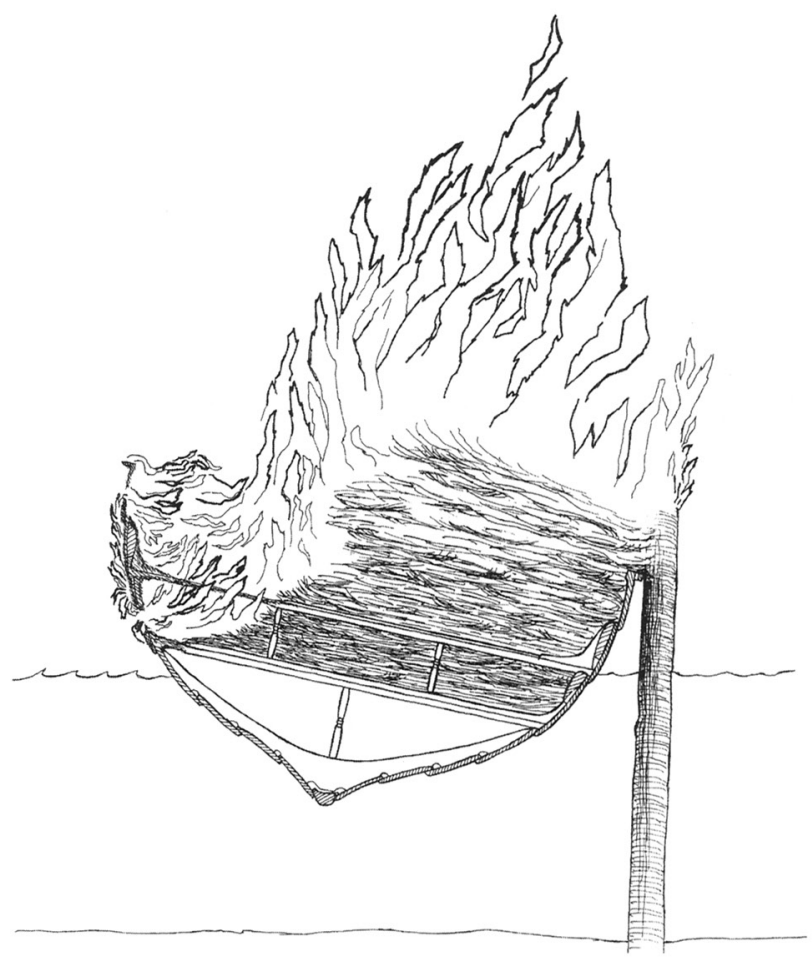

Fig. 11. Hedeby 1-skibet som brander, tegnet af Sune Villum Nielsen. (Efter Crumlin-Pedersen 1997).

The Hedeby 1-ship as a fireship, drawn by Sune Villum Nielsen.

teriseres som værende af kongelig standard. Som type har det været et langt og smalt krigsskib, et egentligt langskib (fig. 12). Længden kan beregnes omtrentligt udfra de bevarede dele til ca. 30,9 m og bredden til 2,7 m, hvilket giver et ekstremt længde/bredde-forhold på 11,4 i forhold til 7-8 for Skuldelev krigsskibene 2 og 5, og 4-5 for de norske skibe fra Oseberg og Gokstad. ${ }^{37}$ Hedeby 1-skibet har antagelig haft en besætning på 60 mand, det dobbelte af, hvad Skuldelev 5-skibet har mønstret, svarende til, at det er næsten dobbelt så langt med omtrent samme bredde.

Dendroanalysen af egeplankerne viser, at dette skib ligesom de andre fundne fartøjer efter alt at dømme er af lokal oprindelse. Det er tankevækkende, at man til et kongeligt skib har kunnet fă ekstremt store egestammer fra skoven på et tidspunkt, hvor andre skibsbyggere har måttet nøjes med at arbejde med langt mindre dimensioner i eg eller har måttet skifte til andre træsorter. Dette understøtter den tidligere nævnte tanke om, at man i Hedeby-regionen har haft regler for skovens udnyttelse, der har givet kongens skibsbyggere retten til de største egetræer, mens andre var henvist til mindre egestammer eller andre træsorter. At indtømmeret i Hedeby 1-skibet omfatter flere træsorter, kan skyldes, at restriktionerne 


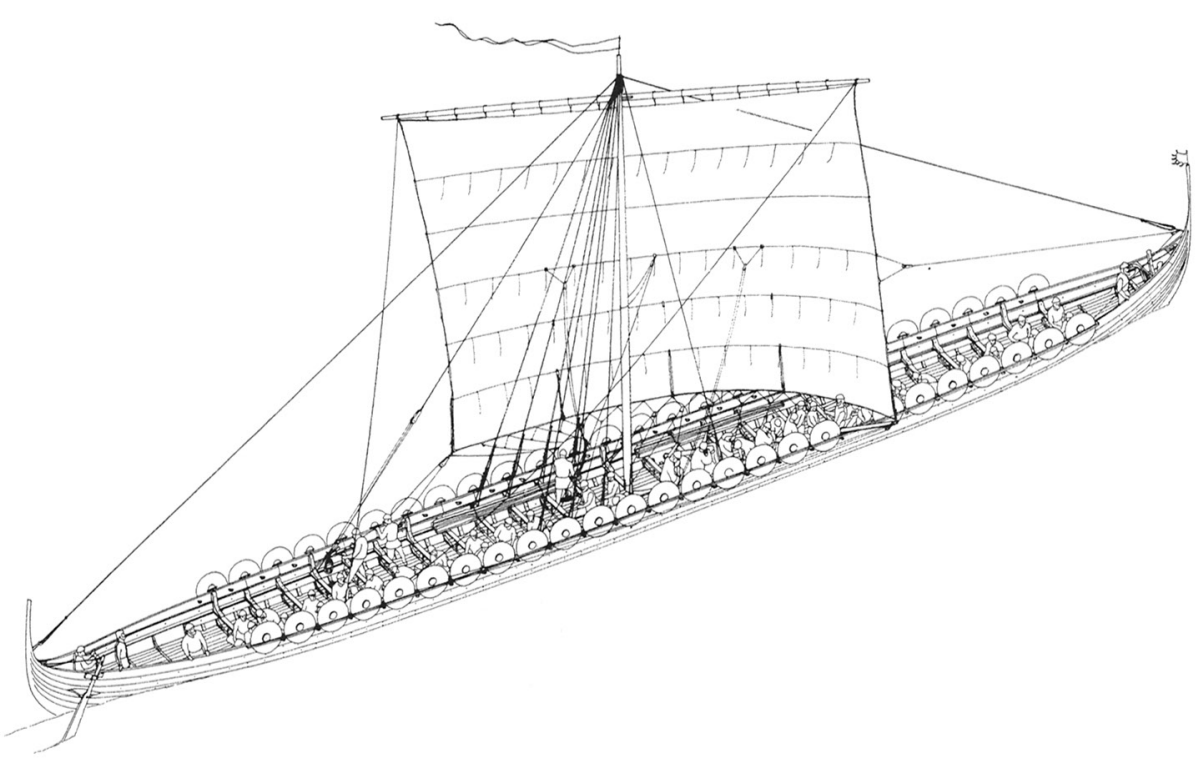

Fig. 12. Hedeby 1-skibet, hypotetisk rekonstruktion. (Efter Crumlin-Pedersen 1997).

Hypothetical reconstruction of the Hedeby 1-ship.

ikke gjalt for krumtømmeret, hvor den kongelige skibsbygger derfor har stået lige med andre i konkurrencen om egnet materiale. En alternativ forklaring kan dog ligge i, at mange spantdele i langskibet er af ask, og valget heraf kan være gjort, fordi denne træsort i særlig grad egner sig til at optage de dynamiske belastninger, som forekommer i et skib af denne art. Asketræs mindre modstandsdygtighed imod råd har formentlig ikke været nogen væsentlig faktor $i$ et skib af denne art, der utvivlsomt har været under tag om vinteren og når det iøvrigt ikke var i brug.

Med det fundne skib står vi altså overfor et kongeligt skib, måske af typen skeid, der i samtidens skjaldekvad prises som danskekongens hurtige, smækre langskibstype. ${ }^{38}$ Skibet har ikke været nyt, da det sank, det viser reparationerne. Regner vi med en aktiv periode på mellem fem og femogtyve år fra skibet blev bygget omkring 985, til det gik op i røg i Hedebys havn, afspejler der sig i dette fund et meget konkret vidnesbyrd om et angreb på byen indenfor perioden 990-1010, et angreb, der efter fundets vidnesbyrd må været lykkedes, set fra angriberens synspunkt. Denne periode har givetvis været en urolig tid i Hedebys historie. Det viser undersøgelserne af halvkredsvolden, der først er anlagt på et sent tidspunkt i byens historie, midt i 900-tallet, men som i sin korte funktionstid, inden Hedeby forlades til fordel for Slesvig by, kan opvise hele ni opbygningsfaser. ${ }^{39}$ 
I forhold hertil er de skriftlige kilders vidnesbyrd om angreb på Hedeby fătallige og fattige. Fra Thietmar af Merseburg erfarer vi om et dansk angreb på en borg i grænselandet, der indtages i 982 eller 983 og brændes af. Det siges ikke direkte, at der er tale om Hedeby, men det antages almindeligvis at være tilfældet. Dateringen af byggefasen for Hedeby langskibet til årene umiddelbart efter 982, og det forhold, at skibet var slidt og repareret inden sænkningen, udelukker dog at vort skib kan være sat ind som brander ved denne lejlighed.

Næste kilde er biskop Eckehard, der i året 1000 på et kirkemøde i Gandersheim klager over, at hans bispedømme er plyndret af hedninge, hans bispeby og kirke ligger øde, og at han ingen magt har over sit bispesæde. Eckehard var biskop i Hedeby/Slesvig og formentlig tillige i Aldenburg/Oldenburg i Wagrien, og der har været diskussion mellem historikerne om, hvilken af disse byer, der var på tale ved denne lejlighed. Johannes Steenstrup har således ment, at klagen gjaldt Aldenburg, ${ }^{40}$ mens andre har henlagt den til Hedeby i forbindelse med Svend Tveskægs formodede kampe med de svenske konger Erik Sejrssæl og Olov Skotkonning, eller tilskrevet den, at Svend selv skulle have plyndret Hedeby. ${ }^{41}$ Tidsmæssigt passer denne kilde til langskibets vidnesbyrd, men Steenstrups holdning har medvirket til at svække dens troværdighed i relation til Hedeby.

Derefter skal vi helt frem til omkring år 1050, før vi hører om nye angreb på Hedeby. Det er et skjaldekvad til norskekongen Harald Hårderådes pris, hvori det hedder:

\section{"Fra ende til anden \\ Hedeby vi brendte, et storvark dér vi gjorde det sander sikkert alle."}

Det kan diskuteres i dette tilfælde, om det overhovedet er Hedeby, der her er på tale, eller om der ikke snarere er tale om den nye bebyggelse på nordsiden af Slien, som vi kalder Slesvig, men som for datidens nordboere hed Hedeby til langt ind i middelalderen. ${ }^{42}$ Dette nordlige bycenter havde øjensynlig på dette tidspunkt taget føringen i udviklingen over den oprindelige Hedeby. Men under alle omstændigheder ville vores skib på dette tidspunkt i givet fald være ca. 65 år gammelt, og en så høj alder er næppe sandsynlig i dette tilfælde, for så havde slid og reparationer været langt tydeligere i fundet.

Ingen af disse tre skriftlige kilder giver således sikkerhed for, at de pågældende angreb havde vort Hedeby som mål, og angribernes herkomst er kun kendt i det sidste tilfælde. Der er imidlertid to skriftlige kilder mere, der, skønt vanskelige at datere, er meget relevante for os, for de 
Fig. 13. Haddeby 1-stenen, fundet 1796 nær Vedelspang. (Efter Jacobsen \& Moltke 1941-42, 2).

The Haddeby 1-stone found 1796 at Vedelspang.

kommer direkte fra selve Hedeby. Det er de to runesten Haddeby 1 og 3, som omtaler to af kong Svends mænd, Erik og Skarde, der omkom i kamp ved Hedeby. ${ }^{46}$ Haddeby 1 -stenen er fundet i 1796 nærVedelspang og bærer indskriften:

"Thorulf, hirdmand hos Svend, rejste denne sten efter sin falle Erik, som fandt doden, da 'drenge' belejrede Hedeby, og han var 'styresmand', en meget velbyrdig 'dreng'"

mens Haddeby 3-stenen, der blev fundet i 1857 ved Busdorf, blot beretter:

"Kong Svend satte stenen efter sin hirdmand Skarde, som var draget vesterpå, men nu fandt doden ved Hedeby."

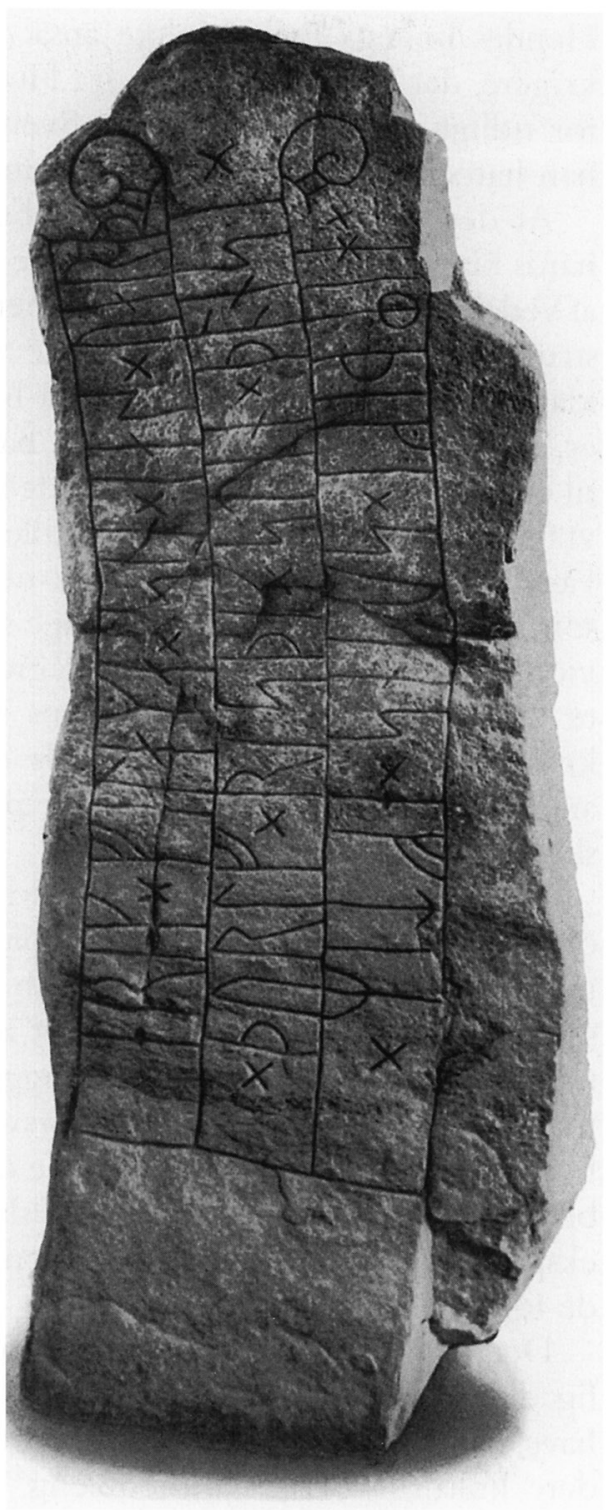

Tydningen af disse udsagn er stærkt omstridt. Umiddelbart kan to konger ved navn Svend komme på tale, Svend Tveskæg (ca. 986-1014) og Svend Estridsen (1047-1076), og de er begge bragt i forslag til datering af stenene, der formentlig refererer til et og samme angreb på Hedeby. Blandt runeforskerne har Lis Jacobsen tolket benævnelsen for de fremmede krigere, drenge, som vidnesbyrd om, at det har drejet sig om norske krigere, og hun har derfor sat belejringen i forbindelse med Harald Hårderådes erobring af byen omkring 1050, d.v.s. under Svend Estridsen. ${ }^{44}$ 
Hendes kollega Erik Moltke anså drengene for at være Svend Tveskægs krigere, der uddrev tyskerne fra Hedeby i $982-983 .{ }^{48}$ Her er vi dog lidt for tidligt på den i forhold til Svend Tveskægs kongetitel, med mindre han har været sin fars med- (eller mod-) konge i dennes sidste år.

At det kunne dreje sig om de begivenheder, der førte til bisp Eckehards klage i året 1000, blev allerede fremført ved den første fremlæggelse af Vedelspang-indskriften i 1799, men siden negligeret på grund af Steenstrups forbeholdne stilling til dette vidnesbyrd. Med Hedeby langskibets klare vidnesbyrd om et angreb på havnen inden for perioden 990-1010 er Eckehard imidlertid tilbage på banen, og der vil være al mulig grund til en fornyet analyse af denne kilde i forhold til såvel runesten som skibsvrag. Vi har i dag lov til at forestille os, at Vedelspang-stenens Svend har været Svend Tveskæg, og at Erik netop har været styresmand på et skib som det, der endte sine aktive dage som brander og sank i havnen som et vidnesbyrd om de voldsomme begivenheder for 1000 år siden, der bragte bisp Eckehard på fortvivlelsens rand. De ni udbygningsfaser i halvkredsvolden bør dog stadig minde os om, at der kan have været talrige andre overfald på Hedeby i denne periode - overfald der ikke er bevaret skriftlige vidnesbyrd om.

Vort Hedeby 1 -vrag bringer os midt ned i den sene vikingetids stridigheder ved grænsen og $i$ forholdet til Norge og Sverige. Man kan undre sig over, at et så fornemt skib er blevet brugt til et så banalt formål som brander. Er det blevet erobret af en fjende, skal man imidlertid ikke undervurdere den hån, der kan ligge $\mathrm{i}$ at brænde et af Hedeby-styrkens fornemste skibe af for næsen af forsvarerne. Hertil kommer, at hvis angriberne er kommet fra Norge, havde de ikke megen glæde af at bringe skibet med sig hjem, da dets lange, slanke form ikke var velegnet til den eksponerede norske klippekyst, men bygget med de indre danske farvande for øje.

Denne korte præsentation af skibsfundene fra Hedeby har forhåbentlig demonstreret det potentiale, et skibsarkæologisk fundmateriale kan have, når det bliver grundigt dokumenteret, analyseret og sat ind $i$ en bredere kulturhistorisk sammenhæng. Vi kan næppe finde mere markante udtryk end disse Hedeby-skibe for grænsebyens mærkesager: søhandelen og rigets forsvar, og de afspejler tillige aspekter af de religiøse brydninger og den etniske mangfoldighed, der har præget dette knudepunkt i Nordeuropas handelsveje. 


\section{NOTER}

1) Knorr 1911.

2) Müller-Wille 1976.

3) Wamers 1994.

4) Steuer 1984. ${ }^{17}$

5) Lüdtke 1985.

6) Wilroth 1986.

7) Behre 1983.

8) Lüdtke 1987

9) Berichte über die Ausgrabungen in Haithabu, Bericht 1-, Neumünster. Die Ausgrabungen in Haithabu, Bd. 1- , Neumünster. Ausgrabungen in Schleswig, Berichte und Studien 1-, Neumünster.

10) Hingst \& Kersten 1955.

11) Crumlin-Pedersen 1969.

12) Stümpel \& Borth-Hoffmann 1983.

13) Crumlin-Pedersen 1997.

14) Malmer 1966.

15) Skaare 1964.

16) Christensen 1964.

17) Ellmers 1972.

18) Crumlin-Pedersen 1997: 172-176.

19) Varenius 1994.

20) Crumlin-Pedersen 1995.

21) Crumlin-Pedersen 1995: 96-98.

22) Carver 1995.

23) Wamers 1994.

24) Ellmers 1980.

25) Crumlin-Pedersen 1997: 252-254.

26) Crumlin-Pedersen 1997: 96-99.

27) Hirte 1997.

28) Hirte 1997: 157.

29) Crumlin-Pedersen 1997: 99-104.

30) Crumlin-Pedersen 1987.

31) Crumlin-Pedersen 1987; Andersen et al. 1997.

32) Her citeret $i$ forfatterens oversættelse fra Radtke 1981.

33) Radtke 1981: 458f.

34) Crumlin-Pedersen 1991; Bill 1997: $155 \mathrm{ff}$.

35) Crumlin-Pedersen 1997: 81-95, 1998.

36) Crumlin-Pedersen 1997: 86.

37) Crumlin-Pedersen 1997: 92.

38) Malmros 1986.

39) Jankuhn 1986: 67.

40) Steenstrup 1927: 77-84.

41) Jacobsen \& Moltke 1941-42, 1: 6-7.

42) Laur 1953.

43) Jacobsen \& Moltke 1941-42, 1: 5-10.

44) Jacobsen 1935.

45) Moltke 1985: 196-200.

\section{LITTERATUR}

Andersen, Erik et al. 1997: Roar Ege - Skuldelev 3 skibet som arkaologisk eksperiment. Roskilde.

Behre, K.-E. 1983: Ernährung und Umwelt der wikingerzeitlichen Siedlung Haithabu. Die Ergebnisse der Untersuchungen der Pflanzenreste. Die Ausgrabungen in Haithabu 8.

Bill, Jan 1997: Den store handels skibe. Ole Feldbæk et al. (red.): Fra stammebåd til skib. Dansk søfarts historie I, s. 155-165. København. 
Carver, M.O. 1995: Boat-burials in Britain: Ancient Custom or Political Signal? The Ship as Symbol in Prehistoric and Medieval Scandinavia. Publications from the National Museum, Studies in Archaeology \& History, vol. 1, pp. 111-124. Copenhagen.

Christensen, A.E. 1964: Birka-Hedeby myntene som kilde til skipets historie på 800-tallet. Norsk Sjøfartsmuseum 1914-1964, s. 81-86. Oslo.

Crumlin-Pedersen, Ole 1969: Das Haithabuschiff. Berichte über die Ausgrabungen in Haithabu. Bericht 3, Neumünster.

Crumlin-Pedersen, Ole 1987: Aspects of Viking-Age Shipbuilding. Journal of Danish Archaeology, vol. 5, 1986, s. 209-228.

Crumlin-Pedersen, Ole 1991: Ship Types and Sizes. Aspects of Maritime Scandinavia AD 200-1200 (ed. O. Crumlin-Pedersen), s. 69-82. Roskilde.

Crumlin-Pedersen, Ole 1995: Boat-burials at Slusegaard and the Interpretation of the Boat-grave Custom. The Ship as Symbol (eds. O. Crumlin-Pedersen \& B. Thye), s. 86-99. Roskilde.

Crumlin-Pedersen, Ole 1997: Viking-Age Ships and Shipbuilding in Hedeby/Haithabu and Schleswig. Ships \& Boats of the North 2. Roskilde \& Schleswig.

Ellmers, D. 1972: Frühmittelalterliche Handelsschiffahrt in Mittel- und Nordeuropa. Offa-Bücher, Band 28. Neumünster.

Ellmers, D. 1980: Fränkisches Königszeremoniel auch in Walhall. Beiträge zur Schleswiger Stadtgeschichte 25, s. 115-126. Schleswig.

Hingst, H. \& K. Kersten 1955: Die Tauchaktion vor Haithabu im Jahre 1953. Germania 33. Heft 3, s. 265-271. Berlin.

Hirte, Christian 1997: Logboats. I Crumlin-Pedersen 1997, s. 148-168.

Jacobsen, Lis 1935: Runeindskrifternes vidnesbyrd om kampene omkring Hedeby. Scandia 8, s. 64-79.

Jacobsen, Lis \& Erik Moltke 1941-42: Danmarks Runeindskrifter 1-2. København.

Jankuhn, H. 1986: Haithabu. Ein Handelsplatz der Wikingerzeit. 8. Auflage. Neumünster.

Knorr, F. 1911: Bootkammergrab südlich der Oldenburg bei Schleswig. Mitteilungen des Anthropologischen Vereins in Schleswig-Holstein 19, s. 68-77. Kiel.

Laur, W. 1953: Sliesthorp, Schleswig, Hedeby und Haddeby. Die Namen von Schleswig-Haithabu und ihre Nachfahren. Namn och Bygd 41, s. 67-83.

Lüdtke, H. 1985: Die mittelalterliche Keramik von Schleswig. Ausgrabung Schild 1971-1975. Ausgrabungen in Schleswig, Berichte und Studien 4. Neumünster.

Lüdtke, H. 1987: Die Keramik von Hollingstedt. Berichte über die Ausgrabungen in Haithabu 25, s. 9 82. Neumünster.

Malmer, B. 1966: Nordiska mynt före år 1000. Acta Archaeologica Lundensia, series in $8^{\circ}$, no. 4. Lund, Bonn.

Malmros, Rikke 1986: Leding og skjaldekvad. Aarbøger for nordisk Oldkyndighed og Historie 1985, s. 89-139.

Moltke, Erik 1985: Runes and their Origin. Denmark and Elsewhere. Copenhagen.

Müller, S. 1897: Vor Oldtid. København.

Müller-Wille, M. 1976: Das Bootkammergrab von Haithabu. Berichte über die Ausgrabungen in Haithabu 8. Neumünster.

Radtke, C. 1981: Schleswig und Soest. Soest. Stadt - Territorium - Reich, s. 433-478. Soest.

Skaare, K. 1964: Skipsavbildninger på Birka-Hedeby mynter. Norsk Sjøfartsmuseum 1914-1964, s. 75-80. Oslo.

Steenstrup, Johs. 1927: De danske Runestene i deres Forhold til Landets og Folkets Historie. Festskrift til Kristian Erslev, s. 61-84. København.

Steuer, H. 1984: Zur ethnischen Gliederung der Befölkerung von Haithabu anhand der Gräberfelder. Offa 41, s. 189-212.

Stümpel, H. \& B. Borth-Hoffmann 1983: Seismische Untersuchungen im Hafen von Haithabu. Berichte über die Ausgrabungen in Haithabu 18, s. 9-28. Neumünster.

Varenius, B. 1994: The Hedeby Coinage. Current Swedish Archaeology 2, s. 185-194. Stockholm.

Wamers, E. 1994: König im Grenzland. Neue Analyse des Bootkammergrabes von Haiðaby. Acta Archaeologica 65, pp. 1-56.

Wilroth, K-H. 1986: Siedlungsarchäologische Untersuchungen in Angeln und Schwansen. Berichte der Römisch-Germanischen Kommission 67, s. 397- 428. 


\section{The Hedeby shipfinds}

In 1897 the 1)anish archaeologist Sophus Muiller suggested that the town of Hedeby (German: Haithabu) on the border between Viking-Age Denmark and Saxony had been situated within the semicircular earthwall at Haddebyer Noor, opposite the town of Schleswig in the present Land SchleswigHolstein. Extensive excavations in the course of the following century by archaeologists from Kiel, Schleswig, Aarhus and elsewhere have now provided evidence for a wide range of activities in Hedeby in the 9th to 11 th centuries and in Schleswig from the 11 th century onwards. The earthworks of Danevirke, spanning the narrow land-bridge of the Jylland peninsula and forming an extensive complex with various building phases from the 7th to the 19th century, have also been studied in detail. Numerous publications dealing with various aspects of this border zone have appeared. ${ }^{1-9}$

The first serious attempt to deal with the maritime aspects of Hedeby was a campaign in 1953 when a helmet-diver was sent down to walk through the mud at the bottom of the former harbour basin of Hedeby. ${ }^{10} \mathrm{He}$ reported on his many finds (fig. 1), which included the wreck of a Viking ship. This was published by the present author in $1969^{11}$ and plans were worked out for the excavation of the ship. This took place in 1979 within a cofferdam. On the same occasion an area between the ship and the Viking-Age shore was excavated, and in 1980) the excavation was expanded to cover a total of c. 2,()()() $\mathrm{m}^{2}$ of the former harbour basin. Further investigations were carried out by seismic recording ${ }^{12}$, which led to the localization and raising of a church-bell, two logboats and parts of two more ships of Viking-Age date, as well as numerous groups of pilings from piers and harbour palisades (fig. 2).

The three ships from the harbour, as well as the logboats and the many loose parts of ships and boats found in the excavations in Hedeby and Schleswig, have now been extensively published ${ }^{13}$, together with the ship depictions on some of the so-called Hedeby-coins of the early 9th century (figs. $3-4)$. These coins have been discussed as sources for the hull and rig of the early Viking-Age ships. ${ }^{14-18}$ Recently, the coins with Nordic motifs have been interpreted as a reflection of an anti-Frankian manifestation by the sons of king Godfred after they had expelled the pro-Frankian Harald Klak in $827 .{ }^{19}$ In this context the ship is probably the lucky ship Skibladnir of the god Freyr. ${ }^{20}$

In 19()8 a large grave was excavated at Hedeby, which contained a ship positioned above a chamber grave for three men..$^{1-2}$ (fig. 5). The burial has been interpreted as the grave of a royal person, possibly Harald Klak, accompanied by his marshal and cupbearer. ${ }^{23-24}$ It may be seen as one of the large royal ship burials characteristic of the transition period leading up to Christianization in 7th-century East Anglia ${ }^{22}$ and in Southern Norway, where the Oseberg mound was erected c. 834 in the period of Harald Klak's missionary efforts in that area. The Hedeby burial ship itself is not preserved, only a plan of the iron rivets, indicating a ship of the Ladby- and Skuldelev 5-types.

The smallest among the three ships in the harbour, Hedeby 2, was a 9-12m-long clinkerbuilt vessel with ironfastened oak planking (as used in Scandinavia) in the bottom, and side planks of beech and pine fastened with small wooden dowels (as used by the Slavs) (fig. 6). The frames were reused from another vessel. This vessel seems to have been built locally by a Slav (or Saxon) boatbuilder, influenced by Danish traditions, in the final quarter of the 10th century. The reused frames and the use of beech planks indicate that access to the best oak trees for shipbuilding was limited. This interpretation is supported by the fact that one of the two logboats found in the harbour is of beech, ${ }^{27}$ the earliest example of the common use of this species of wood for logboats in medieval Denmark.

The wreck Hedeby 3 was located during 
the seismic survey in the southern part of the harbour, and divers recovered several parts of the internal timbers and a few pieces of planking. Dendroanalysis has demonstrated that the ship was built locally c. 1025. It was a sturdily built cargoship of a type similar to Skuldelev 1 but with a cargo capacity of as much as c. 60 tons, according to the hypothetical reconstruction (figs. 7-8) giving a length of c. $22 \mathrm{~m}$ and a width of $6.25 \mathrm{~m}$. The internal timbers of the ship were made from a broad range of wood species. A good parallel to this large cargoship from Hedeby/Schleswig is found in the Life of Thomas of Canterbury from c. 1175, describing the problems of launching a new cargoship built at Schleswig by a local merchant in company with the king. ${ }^{32}$ In both cases the ships were no doubt examples of the Danish ships built for the expanding Baltic trade in the 11 th12th centuries (fig. 9).

The wreck excavated within the cofferdam, Hedeby 1, was the remains of a longship of elegant construction. Only parts of the midship and forward port side were preserved, with extensive traces of charring along the upper edge of the fourth port plank (fig. 10). Evidently the ship had been used as a fireship in an attack on the harbour defences, burning with a heap of inflammable materials stacked onboard (fig. 11). The ship was built from exceptionally long oak planks, up to c. $10 \mathrm{~m}$ long, radially split planks, assembled with carefully shaped tongue-scarfs. Loose elements of frames, beams and knees were found and these provided evidence for the reconstruction of the original lay-out of the ship as a very long and narrow ship, c. $30.9 \mathrm{~m}$ in length and only $2.7 \mathrm{~m}$ in width, possibly a Danish royal longship of the skeid type (fig. 12). The building materials for the ship had been felled locally within a few years after AD 982 and the ship had been repaired, indicating an age for the ship of 5-25 years at the time of its sinking, thus dating the attack on the town to the period c. 990-1010.

There are three different sources that may bear testimony to this event. One is the report by bishop Eckehard of Hedeby/Schleswig and Aldenburg to a church meeting in Gandersheim in 1000 ) that his episcopal seat had been sacked by heathens and destroyed. The other two are the runic stones Haddeby 1 and 3, both found near Hedeby and both commemorating warriors who died at Hedeby, serving King Svein. These stones have been seen in relation to either Svein Forkbeard (c. 986-1014) or Svein Estridsen (1047-1076) and they have been discussed primarily in relation to events at Hedeby in 982-983 and c. 1050 (44-46).

The Haddeby 1 stone (fig. 13) commemorates Erik, who died when 'drenge' (= Nordic warriors) besieged Hedeby. This might indicate that the heathens reported by Eckehard were Norwegians, and the fact that a fine slender Danish longship was burned in the attack would thus be understandable, as this ship-type built for the sheltered Danish waters was not suitable for general use along the coast of Norway.

Thus the shipfinds from Hedeby serve us as important primary sources for important aspects of the history of this border region, trade and the defence of the country, and they reflect the religious conflicts and the ethnic variety of this North European trading centre.

Ole Crumlin-Pedersen

Marinarkæologisk Forskningscenter Nationalmuseet i Roskilde/ Centre for Maritime Archaeology National Museum of Denmark, Roskilde 